\title{
UNDERSTANDING THE IMPACT OF INTERNAL MARKETING PRACTICES \\ ON BOTH EMPLOYEES' AND MANAGERS' ORGANIZATIONAL COMMITMENT IN ELDERLY CARE HOMES
}

\begin{abstract}
Purpose: The objective of our article was to unfold the relationship between the antecedents of employee and manager commitment, using internal marketing practices, in elderly care homes.

Design/methodology/approach: Based on survey data drawn from elderly care homes in Finland, we tested several literature driven hypotheses of how internal marketing practices (internal value exchange, internal communication, and training) relate with employee and manager commitment. Hence, we compare the organizational commitment of two groups. Additionally, we tested the moderating role of public residence on these relationships.
\end{abstract}

Findings: Our study revealed that there are differences in the antecedents to employee and manager commitment in terms of internal value exchange. This is an important extension to the literature of employee and management commitment in which the antecedents to management commitment, especially, are under-investigated, and where the relationship between the antecedents of the two types of commitment are not studied.

Practical implications: While different emphases on internal marketing programs for employees and managers must be implemented in order to re-create work environments that could lead to improved service provision, we suggest that facilitating open and honest communication and exchanging values in care homes is a crucial step for improving service quality and employee and manager retention. 
Originality/value: This study has high value to both the literature and practice as high service quality can be provided when both employee's and manager's commitments are in place, and without understanding the differing antecedents and their relationships, it is hard to establish both types of commitment in an organization. We believe that this new insight is useful in improving the service quality and employee and manager retention of organizations.

Key words: antecedent; elderly care home; employee; internal marketing; manager; organizational commitment Paper type: Research paper 


\section{Introduction}

Employee retention is critical to the long-term success of most of organizations, and a committed employee base is especially relevant in the global health care community, where the retention of caregivers is increasingly important in light of a world-wide shortage of nurses (Pelter et al., 2013; World Health Organization, 2009). Given that it is difficult to increase the supply of new nurses entering the profession, one logical approach is to find ways to increase the job satisfaction and retention of existing nurses (Laine, van der Heijden, Wickström, Hasselhorn \& Tackenberg, 2009).

High employee turnover is a problem not only in the field of elderly care, but generally in the service sector (Wang, 2014). Previous studies confirm that organizations with highly committed employees have lower turnover rates (Allen and Meyer, 1990). Therefore, a number of organizational and service marketing scholars have been investigating the concept of organizational commitment (Ashiil et al., 2008; Cheung \& To, 2010; Mayer \& Allen, 1991; Ramseook-Munhurrun, Naidoo \& LukeaBhiwajee, 2009; Wang, 2014; Zeithaml et al., 1990).

Driven by this phenomenon of problematic service quality in elderly care homes in developing countries, we endeavour to make theoretical contributions focusing on the role of employee and manager organizational commitment in improving service quality.

In the field of marketing, the Philosophy and the Theory of Internal Marketing (IM) have been developed to integrate employees of an organization as the key mediators in improving customer satisfaction and service quality (Ahmed \& Rafiq, 2003). Internal marketing is defined as "concerned with making available internal products (jobs) that satisfy the needs of a vital internal market (employees) while satisfying the objectives of the organizations" (Berry et al., 1976, p. 8). If organizations become keen to fulfil the requirements of their employees, the impact would be positive in terms of job 
satisfaction and employee commitment. As a result, the IM theory assumes that employees pay greater attention to the customers, who thereby benefit from a better quality of service.

Early studies have found that the relationship between the employee and superiors results in positive organizational outcomes (Elmadağ et al., 2008; Wang, 2014). However, little attention has been paid to organizational commitment from the perspective of interpersonal relationships that takes into account both employee's and manager's commitments and examines their relationship (Elmadağ et al., 2008; Wang, 2014). Particularly, antecedents to manager commitment have not been explored in earlier studies. In the present study, we build on Wang's (2014) study and extend it by focusing on the antecedents of employee's and manager's commitments, which is Internal Marketing (IM). Studying these relationships is important because while high service quality can be provided when both employee's and manager's commitments are in place, the two types of commitment are expected to be different. Hence, we intend to contribute to the literature by: unfolding the relationship between the antecedents of employee and manager commitment, using internal marketing practices, in elderly care homes.

The paper is organized as follows. First, the literature relating to organizational commitment and IM is reviewed, and related hypotheses are developed. The next section presents the methodology of the study. Then, the empirical research results are reported. Finally, the discussion and implications are presented, and limitations and future research directions, as well as conclusions, are provided.

\section{Literature review and hypotheses development}

\subsection{Organizational commitment}


Organizational commitment is multidimensional and has been conceptualized through a variety of interrelated constructs likely to influence employee satisfaction, retention and performance (Peltier et al., 2008). Among these, the most widely adopted definition conceptualizes organizational commitment as "the relative strength of an individual's identification with and involvement in a particular organization" (Mowday, Steers \& Porter, 1979, p. 226). Organizational commitment encompasses: (1) value commitment, the strong belief in, and acceptance of, organizational objectives and values; (2) effort commitment, the dedication to benefiting the organization; and (3) retention commitment, the willingness to remain a member of the organization (Chang \& Chang, 2009, p. 93-94). Another well-established categorization of organizational commitment used in service marketing has three dimensions of affective commitment (employee's emotional attachment to, identification with, and involvement in the organization), continuance commitment (an awareness of the costs associated with leaving the organization), and normative commitment (a feeling of obligation to continue employment) (Mayer \& Allen, 1991, p. 67).

Besides employees' and manager's organizational commitments in relationship marketing, which are the focus of the present study, consumer's or customer's commitments towards the service organization and consumer's or customer's commitments towards the individual employee or representative of the firm are recognized (Jones, Taylor \& Bansal, 2008). This type of research defines, in general, relationship commitment as a desire to maintain a relationship between exchange partners (Bansal et al., 2004; Gustafsson, 2005; Hur, Park \& Kim, 2010; Jones et al., 2008; Richard \& Zhang, 2012). Previous studies indicate a positive relationship between service quality and customer commitment (Harza \& Sirvastava, 2009). It is said that relationship commitment is an antecedent to customer loyalty (Gustafsson, 
2005; Hur et al., 2010; Richard \& Zhang, 2012), and that commitment can also lead to cost reduction, higher profits and positive word-of-mouth (Hur et al., 2010). The majority of this stream of literature conceptualizes relationship commitment into two dimensions: affective commitment and calculative commitment (Gustafsson, 2005; Hur et al., 2010; Rendall, Gravier \& Prybutok, 2011; Richard \& Zhang, 2012). Affective commitment is motivated by a positive feeling and attachment to the organization or employee, while calculative commitment is motivated by the instrumental, rational and economical influences of the relationship (Richard \& Zhang, 2012).

\subsection{Focus of the study: employee and manager organizational commitment}

In the field of service marketing, and particularly in the context of hospitality and elderly care management, customer or resident (and the family and relatives) satisfaction has been suggested as one of the consequences of service quality (i.e. "In the service industry, definitions of service quality tend to focus on meeting customer's needs and requirements and how well the services delivered meet their expectations" [Ramseook-Munhurrun, Naidoo \& Lukea-Bhiwajee, 2009, p. 543]). For instance, Kleinsorge and Karney (1992) indicate that the elderly care sector has become more sensitive to improving its service quality due to an increase in customer demands (patients and residents), as well as those of relatives, and thus, resident satisfaction is the critical indicator.

However, according to several authors, business success depends on the performance of the employees who perform services and their interaction with the customers (Ramseook-Munhurrun et al., 2009; Ashiil, Rod \& Carruthers, 2008) Accordingly, it is suggested that in order to provide high service quality, organizations need to first provide employee satisfaction (Ramseook-Munhurrun et al., 2009). As such, employee 
satisfaction turns out to be an important antecedent to service quality, as well as the resulting customer satisfaction (Zeithaml, Parasuraman \& Berry, 1990).

There have been studies that take into account the role of employees in investigating service quality and customer satisfaction, and there is vast evidence that employee satisfaction leads to customer satisfaction (Zeithaml et al., 1990). Stershic (1994) showed that the levels of customer satisfaction are greater in those organizations where the employees are aware of the impact of quality service provisions. In this stream of research, the importance of job satisfaction (Bowers \& Martin, 2007; Lings \& Greenley, 2005; Mudie, 2003) and employee commitment (Ballantyne, 2003; Peltier et al., 2012), as well as the relationship between employee and resident satisfaction (Liu, 2007), have been explored and determined to be important. Due to the nature of the work, in which the employees often develop close relationships with the residents, the employee satisfaction and commitment enormously affect the customer satisfaction.

The relationship between job satisfaction and commitment is rather well-established (Andreassen \& Olsen, 2008; Ashiil et al., 2008). Research has found employee job satisfaction to be a key determinant of organizational commitment, and according to Mukjerhee and Malhotra (2006), job satisfaction exerts a positive influence on the organizational commitment of the employees. Particularly, in the field of hospitality and elderly care management, there has been more research that measures employee job satisfaction aspects (Ballantyne, 2003; Bowers \& Martin, 2007; Lings \& Greenley, 2005; Liu, 2007; Mudie, 2003; Peltier et al., 2012) than commitment aspects (Peltier et al., 2008; Peltier et al., 2012). Employee commitment is a more stable concept than job satisfaction, more directly affecting employee turnover and business success (Ashiil et al., 2008). Therefore, we aim to expand the current literature with regard to the latter. Employee commitment can be defined as, "employees' beliefs in the goals and values 
of the organization, their willingness to exert effort, and their intention to maintain membership of the organization” (Mowday, Steers \& Porter, 1979, p. 226).

Another type of commitment that is well-studied is management commitment (defined as: "consciously choosing quality initiatives as operational and strategic operations for the organization, and engaging in activities such as providing visible quality leadership and resources for the adoption and implementation of quality initiatives" [Cheung \& To, 2010, p. 261]). Mixed findings have been reported on the relationship between management commitment and customer satisfaction (Ashiil et al., 2008; Cheung \& To, 2010; Prabhu \& Robson, 2000). Cheung and To (2010) suggested that effective employee involvement might mediate the effects of management commitment on service quality. Earlier research works have found that the quality of service provided by employees is influenced by managerial behaviours and commitment (Elmadağ, Ellinger \& Franke, 2008). However, according to Wang (2014) and Elmadağ et al. (2008), little attention has been paid to organizational commitment from the perspective of interpersonal relationships, although earlier research has found a relationship between employees and superiors resulting in positive organizational outcomes. In addition, earlier studies on management commitment demonstrate low focus on exploring the antecedents of the construct. Answering the research call to investigate the organizational commitment of service firms from the relationship between employee's and manager's commitments, we build on Wang's (2014) study and extend it by paying attention to the antecedents of employee's and manager's commitments, that is, Internal Marketing (IM). The relationship between employee's and manager's commitments forms a fundamental part of the work environment of an organization (Wang, 2014). High quality service cannot be provided if employees only are committed, high service quality and customer satisfaction can be achieved more 
effectively when both employees and managers are committed. However, how these two commitments differ and where the difference is derived is under-investigated. This is where we intend to contribute.

Although relatively little is known about service firms' utilization of developmental and motivational approaches for improving employee's organizational commitment (Elmadağ et al., 2008), research is emerging to investigate how Internal Marketing (IM) can be utilized to create loyal nursing staff that is fully committed to meeting organizational goals and patient needs (Chang \& Chang, 2007; Peltier et al., 2008; Palter et al., 2013; Tsai \& Tang, 2008). Malhotra and Mukherjee (2003) showed that there was a positive correlation in companies that paid more attention to the needs of the employees and commitment; more specifically, that emotional loyalty had a positive influence on attention given to external clients.

\subsection{Internal Marketing (IM)}

It is said that in order to create long lasting success in organizations, the company, employees and the resident commitments must be linked (Berry, 1995; Peltier et al., 2008). According to Ahmed and Rafiq (2003), in order to build employee commitment, a company must know and understand its people and itself. By looking after the needs of the employees, the Theory of Internal Marketing (IM) provides a clear signal to the internal market that the company values its employees.

Thirty years ago, Berry, Hensel and Burke (1976) introduced the concept of internal marketing into the marketing literature (Wieseke, Ahearne, Lam \& Dick, 2009, p. 123). Having its origins in total quality management (TQM) (Ballantyne, 2003, p. 1243), internal market orientation is based on the principle that organizations should treat their employees as they would their clients, creating a positive impact on the workplace 
atmosphere, employee commitment and loyalty, and organizational success (cf. Anaza \& Rutherford, 2012; Bowers \& Martin, 2007; Lings \& Greenley, 2005; Mudie, 2003; Peltier \& Scovotti, 2005; Palter et al., 2013). The logic of this idea is that by satisfying the needs of internal customers, an organization should be in a better position to deliver the quality desired to satisfy external customers (Ahmed \& Rafiq, 2003; Malhotra \& Mukherjee, 2003). Within a healthcare context, internal marketing efforts have been found to increase patient service quality (Tsai \& Tang, 2008) and create a sense of belongingness to the organization (Bellou \& Thanopoulos, 2006; Palter et al., 2013). Cooper and Cronin (2000) showed that internal market orientation in elderly care homes has the potential to increase loyalty, thereby reducing undesired staff turnover.

Despite the importance of IM, one serious drawback in the literature is the fact that its study tends to remain conceptual in nature, and that there remains incongruity in its operationalization (Anaza \& Rutherford, 2012; Palter et al., 2013; Wieseke et al., 2009), especially with regard to how the antecedents of IMO directly and indirectly impact job satisfaction and loyalty are underdeveloped (Palter et al., 2013).

Despite the lack of operationalization in the IM literature, a number of key elements of IM have been identified: communication, training, education and information generation (Gummesson, 1991); motivating and developing, educating or training employees (Grönroos, 1990; Cahill, 1995; Foreman \& Money, 1995; Varey, 1995); and attracting, hiring and retaining employees (Berry \& Parasuraman, 1991; Foreman \& Money, 1995; Anaza \& Rutherford, 2012; Ahmed, Rafiq \& Saad, 2003). The conceptualization of IM has been closely linked to human resource management practices; however, IM practices differ from human resource practices based on the argument that the former advocate employee benefits over those of the firm (Anaza \& Rutherford, 2012) 
IM practices are useful theoretical tools to identify the underlying dimensions of employee and manager commitment in elderly care homes (cf. Palter et al., 2013). Given this background, we formulate hypotheses on how IM is generated and maintained, and how it fosters employee and manager commitment. Figure 1 exhibits our theoretical model.

(Insert figure 1 about here)

\subsubsection{Internal value exchange}

According to several scholars, the generation of an internal market orientation is a crucial first step to achieving organizational objectives (Lings \& Greenley, 2005; Gounaris, 2008). Subsequent developments in the internal marketing literature have emphasized the importance of offering employees a clear vision that is worth pursuing (Wieseke et al., 2009). Shared values form the basis for the development of norms and behaviours in an organization (Gounaris, 2008). It is hard for organizations to be successful if their employees fail to accept their missions, goals and objectives (Malhotra \& Mukherjee, 2003). Value propositions mean different things in different places, and according to Ballantyne (2003), internal marketing should serve the valued interests of the individual employee and the valued interests of the organization in transforming itself into a customer-focused entity. When organizational values produce norms and behaviours that are intrinsically motivating and supportive for the employees, this enhances the organizational commitment of the employees and influences the employees' willingness to serve customers, because their efforts are an integral part of the total experience customers receive from the service organization (Gounaris, 2008; Malhotra \& Mukherjee, 2003). Indeed, according to previous research, 
extrinsic compensation is not enough to satisfy employees and make them committed to their jobs (Sasser \& Arbeit, 1976; Osterloh \& Frey, 2000).

The effectiveness of such an exchange of values depends of the degree of commitment to the value of an offer, and its fulfilment, from both the manager's and employee's points of view (Ballantyne, 2003). Although the literature on management commitment has not explored its antecedents, the literature on organizational commitment supports that value exchange and sharing, and the creation of coherent organizational culture, create commitment among organizational members, including managers (Saffold, 1988). Hence, internal value exchange is a crucial antecedent to both employee and manager commitment. However, there might be a difference in the magnitude of such an influence. While it might be more critical for employees to exchange values with the managers in order to be committed to the workplace, such an exchange might be less important for the managers. This may be because effective value exchange could provide employees with a chance to actively engage in customer evaluations, problems solving and generate new ideas, thus, having more responsibility to the job; managers already have the authority to act independently and make key customer decisions without the approval of others (cf. Cheung \& To, 2010). Thus, we suggest the following hypotheses:

H1.1. Internal value exchange positively affects manager commitment.

H1.2. Internal value exchange positively affects employee commitment. This effect is even stronger for employee commitment than manager commitment.

\subsubsection{Internal communication}


Once it has been generated, an internal market orientation has to be maintained. Today, the way that organizations communicate with their internal markets, known as Internal Communications (IC), is considered to be one of the most essential aspects of internal marketing (Anaza \& Rutherford, 2012; Ferdous, 2008). It is said that internal communications efforts within organizations foster employee trust and commitment (Ferdous, 2008). According to previous research, both horizontal (e.g. between employees or between managers) and vertical communications (e.g. between management and employees) are necessary to maintain an internal market orientation (Lings, 2004; Gounaris, 2008; Willem et al., 2007).

While both types of communication certainly positively affect commitment, or employees, vertical internal communication might be more important than horizontal internal communication. Since through vertical communication, when employees feel they are effectively involved in decision making, their opinions are taken into account for improving service performance, or they feel recognized by the manager, their job satisfaction and commitment might be enhanced (Cheung \& To, 2010). Internal communication is said to be one of the factors with the greatest impact on job satisfaction, trust and commitment, thereby strengthening the firm-employee relationship and ultimately affecting profitability by enhancing customer satisfaction (Ahmed et al., 2003; Ferdous, 2008). The content of internal communication is wide ranging, from employee needs to more strategic objectives, challenges and future plans, which all must be adequately communicated. Stan et al. (2004) states that internal services provisions, such as information systems, market research, training, accounting and facilities support, are critical components of internal communication. Research in health care contexts suggests that increased communication between nursing staff and 
other health care team members improves job satisfaction and leads to better care and attention (Peltier et al., 2003).

On the other hand, for managers, while vertical communication is certainly important to maintain positive interpersonal relationships with the employees and increase the organizational commitment (Wang, 2014), horizontal internal communication between managers might be more important than vertical internal communication. Managers are in the position of making important strategic decisions, and this follows with a high level of stress in their work. In such a situation, what eases their stress and enhances their job satisfaction and commitment might be the communication with other managers, more than with their subordinates. Thus, we suggest the following hypotheses:

H 2.1. Internal horizontal communication positively affects employee commitment.

$H$ 2.2. Internal vertical communication positively affects employee commitment. For employees, this effect is even stronger than internal horizontal communication.

H 2.3. Internal vertical communication positively affects manager commitment.

H 2.4. Internal horizontal communication positively affects manager commitment. For managers, this effect is even stronger than internal vertical communication.

\subsubsection{Training and development}

Internal market orientation cannot be solely maintained through horizontal and vertical communications. Some research has identified the necessity for training or personal development in organizations (Lings \& Greenley, 2005; Gounaris, 2008), and it has been demonstrated that training correlates positively with job satisfaction, 
commitment to the company and trust in management (Bansal et al., 2001). Training and development are motivational tools used to foster continued learning (Anaza et al., 2012).

Thornton (1994) proposed the development of training programs aimed at employees in the elderly care home sector to prepare them for marketing responsibilities, and in this way strengthen their roles within the organization. It has been determined that the empowerment of employees gives them greater access to resources and information, and provides motivation that impacts positive outcomes (Gill, White \& Camereon, 2011). Workplace environments allowing nurses more access to information, support and opportunities to learn and grow over time reflected higher levels of job satisfaction (Peltier et al., 2008). Customers usually appraise the service quality of an organization based on their experience of their interactions with the service providers. Employees are able to satisfy customers' needs if they have the sufficient skills, knowledge and abilities to effectively interact with their customers (Tsai \& Tang, 2008). Earlier studies have demonstrated that employees are more committed to organizations that invest more in customer service training (Ashii et al., 2008).

Contrarily to such literature signifying the importance of training to employee commitment, very little is suggested that providing training for employees would facilitate a manager's commitment. Although Ashii et al. (2008) suggested that management commitment to provide training enhances employee commitment, it is still under-investigated whether it enhances the commitment of managers themselves. Although having the burden of training the subordinates might lead to workplace stress for the managers, since managerial training occurs in the workplace as part of the dayto-day relationship between employee and manager (Elmadağ et al., 2008), we could assume that managers might feel satisfied and committed if they can see their 
subordinates grow and learn. Also, by providing proper training, managers themselves might have less problems in the workplace. Thus, we suggest following hypotheses:

H 3.1. Training positively affects manager commitment.

$H$ 3.2. Training has an even stronger positive effect on employee commitment than manager commitment.

\subsubsection{Moderating role of the type of residence}

Earlier studies on the health care sector have shown that public organizations are more bureaucratic and worse managed compared to private sectors. Usually, public elderly care homes are less expensive when compared to private ones, and thus, the service quality is said to be lower (Sinervo et al., 2010). While the operational priority for public residences is public service and collective choice, for private ones it is governed by the market forces and individual choice. In public residences, the work force consists of public servants, while in private ones they are paid employees in managerially controlled firms. Thus, there are clear differences in the organizational structure, governance, operational priorities and ways to manage human resources in the two types of residences (Tynkkynen, 2013). Therefore, an assumption can be made that the type of residence might moderate the above eight relationships specified in the hypotheses. As examining the moderation role is not the key focus of the study, we limit our analysis in posing an additional general research question as following: Does the type pf residence moderate the relationship between the internal marketing practices and employee and manager commitment?

\section{Methods}




\subsection{Data description}

Keeping our research question in mind, we began data collection by investigating the secondary data available from the Ministry of Social Affairs and Health and Statistics in Finland. Based on the secondary data, we could identify the historical and recent trends in the industry. Quantitative methodology was chosen since the topic of the study builds on previous quantitative works (e.g. Wang, 2014). In conjunction with the secondary data analysis, two pre-tests of the questionnaire were undertaken following Churchill's (1979) suggestions. The questionnaire was piloted by means of 15 interviews with managers of hotels and hotel chains in order to identify any bias or difficulties with item interpretation. The questionnaire was then reviewed again by ten experts, including both university lecturers and professionals in the field. On the basis of the comments and evaluations from both the experts and respondents from the interviews done in the hotels, we re-worded some questions for the sake of improving the readability and understandability of the questionnaire.

The questionnaires were distributed and collected electronically via a web-based survey management tool: Webropol. We obtained a list of elderly care homes in Finland from Fonecta's list of both private and public elderly care homes in Finland (Fonecta is Finland's largest customer relationship marketing, site tracing, online advertising and generating agency).

We targeted both managers and employees of the elderly care homes to fill out the questionnaire. The participants were informed that the purpose of the data collection was to conduct research and that their responses were going to be used in a research study. They also had the choice to decline to participate in the study. Due to the difficulty in gaining access to the employees, we used a purposive networking approach to build the sampling frame for the employees. We asked the managers to forward the 
questionnaire to two or three of his/her subordinates. This could be considered to be a methodological limitation of this study, since the employees might feel it to be difficult to provide negative answers. However, in order to reduce this problem, the questionnaires were directly collected by the authors (the managers were not able to see the answers), and both the anonymity and confidentiality of the employees were assured. Our total sample size was 231, of which 209 were used after omitting the responses with missing values. The sample consisted of 112 managers and 97 employees; 77 private elderly care homes and 132 public elderly care homes. Only 10 out of 209 respondents were male; therefore, we can see the female dominance in the industry.

First, the samples were divided into managers and employees, with the aim of contrasting any significant differences which could occur in both segments; then, in the final stage of regression modelling, the two groups were united and analysed. The data was collected between September of 2012 and March of 2013. The survey questions were translated and then back-translated from English to Finnish to reduce comprehension problems.

\subsection{Measures}

The IM variables were directly measured using previously established and validated scales. The internal value exchange was operationalized based on Lings and Greenley's (2005) and Gounaris' (2008) scales on the generation of IM. Internal value exchange was measured using a four-item seven-point Likert-type scale ranging from " $1=$ strongly disagree" to " $7=$ strongly agree." The scale was adapted from the original scales, as suggested by Gounaris (2008), to fit with the intended sample of service employees.

Internal communication was operationalized using Gounaris' (2008) scale, where five items are used to measure internal vertical communication and four items are used 
to measure internal horizontal communication. As a result of the factor analysis (principle component analysis with varimax rotation), one item from the internal vertical communication was removed. The responses were assessed from " $1=$ strongly disagree" to " $7=$ strongly agree".

The scale for training was adapted from Gounaris' (2008) work as well. While Gounaris' (2008) scale is composed of four items, as a result of factor analysis (principle component analysis with varimax rotation), our scale was based on three. The response category for this question was anchored on a seven-point Likert scale ranging from " $1=$ strongly disagree" to " $7=$ =strongly agree".

Our dependent variable, "commitment", was measured with the three items used by Ruizalba et al. (2014). These items reflect the three dimensions of commitment (affective, continuance and normative) suggested by Allen and Mayer (1990). The participants responded to questions that were anchored on a seven point Likert-type scale from " $1=$ strongly disagree" to " $7=$ strongly agree". The measures used in the study are summarized in table 1.

(Insert table 1 about here)

Each sub-dimension was adjusted according to a KMO and Cronbach's alpha analysis. As table 2 shows, all of the factors adjust adequately to obtain values above 0.6 (Hair, Black, Babin \& Anderson, 2010).

(Insert table 2 about here)

\subsection{Analysis}


Tests were performed to check whether there were any differences between the manager and employee perceptions in organizational commitment stemming from the IM variables.

The data set was standardized before running the tests. We tested the theoretical model by first examining the descriptive statistics and inter-correlations between the variables. Second, comparative measurement analyses of each of the factors studied were conducted using independent samples T-tests. Finally, linear regression models were run. This data analysis technique was chosen based on the research question, structure of hypotheses and nature of data collected.

The correlation matrix was used to check for potential multicollinearity problems amongst the independent variables. Table 3 shows the correlation matrix for the variables.

(Insert table 3 about here)

First, the liner regressions were run separately for the managers and employees. The linear regression analysis was applied in three models: the first contained the independent variables; the second model contained the independent variables and the dummy variable (type of residence); and the third model contained the independent variables, the type of residence and the interaction term between the independent variables and the type of residence. The categorical variable, type of residence, was coded to public $(=1)$ and the others $(=0)$. Our analysis followed the commonly used hierarchical moderated regression analysis (three regression equations tested step by step) (cf. Wang, 2014) to test for the moderating effect of the type of residence. Models 
1 and 2 were useful to test the hypotheses from 1.1 to 3.2 , and model 3 was used to test the additional research question on the moderating role of type of residence.

Finally, separate linear regression models (models 4 to 8 ) were run to compare the regression coefficients between the managers and employees $(\mathrm{H} 0: \mathrm{Be}=\mathrm{Bm})$. In this stage, the two groups (employee and manager) are analysed together. A dummy variable called 'employee', which is coded 1 for employees and 0 for managers, and variables called EmpIVE, EmpIVC, EmpIHC and EmpTR, which are the products of 'employee' and the extant variables, were produced. We then used the new variables as the independent variables in the regression equation (Institute for Digital Research and Education). In addition, in order to verify the results concerning the moderating role of the type of residence, interaction terms between the newly created independent variables and type of residence were tested.

\section{Results}

The descriptive information for the variables and the results of the independent samples T-tests are shown in table 4. In terms of descriptive statistics, we report the real averages of the summated scales in Table 4, rather than the standardized scores in order to increase the interpretability of the results.

(Insert table 4 about here)

The results from the independent samples T-tests were further investigated with OLS regressions. Table 5 and table 6 show the results of the OLS regressions for managers and employees separately. Checking the bivariate Pearson correlations (table 3), IVE, IVC and IHC seem to be correlated with each other, and the maximum VIFs for both 
managers $(=1.658)$ and employees $(=3.045)$ are acceptable in models 1 and 2. (The high VIFs caused by the inclusion of powers or products of other variables in model 3 can be ignored, because the $p$-value is not affected by the multicollinearity.)

(Insert table 5 and table 6 about here)

In terms of the variable internal value exchange, we can see that it continues to be a significant predictor for the job commitment of the employees throughout models 1 through 3. However, for the managers, it does not influence the job commitment significantly. Therefore, hypothesis 1.1 is rejected, while hypothesis 1.2 is accepted.

In terms of the variable of internal vertical communication, we can see that it continues to be a significant predictor for the job commitment of the employees in models 1 and 2. Equally, for the managers, it continues to be significant throughout models 1 and 2. When we observe the variable for internal horizontal communication for the employees, it is not a significant predictor for job commitment in any model. Contrarily, for managers, it is indeed a significant predictor in model 1 but not in model 2. Comparing vertical and horizontal communications for managers, in model 1 , horizontal communication is significant at the 0.01 level and not significant in model 2 while, vertical communication is significant at the 0.05 level in both models 1 and 2 . Consequently, based on our interpretation on model 2, we can say that for the managers, the vertical communication is more significant.

Consequently, for employees, hypothesis 2.1 is rejected, while hypothesis 2.2 is accepted. For managers, hypothesis 2.3 is accepted, while hypothesis 2.4 is rejected

Training does not seem to be a significant predictor for job commitment, either for employees or managers. Thus, hypotheses 3.1 and 3.2 are rejected. 
Finally, paying attention to the interaction effects for employees, after adding the interaction effects the R2 did not change much. In addition, all of the interaction effects are not significant. Therefore, in the case of the employees, moderation did not occur in any case. Also, for the managers, although in model 2 the type of residence seems to have a significant effect on the commitment, after adding the interaction effects the R2 did not change much. In addition, all of the interaction effects are not significant. Therefore, in the case of the managers as well, moderation did not occur in any case. Thus, our research question on the moderating role of type of residence was not supported.

Turning attention to table 7 , we can see that none of the newly created independent variables EmpIVE, EmpICV, EmpICH and EmpTR serve as significant predictors to employee and manager commitments. These results mean that although employee and manager commitment did have distinct antecedents, statistically their difference is not that significant. This also means that hypothesis 1.2 might have to be partly (the second half of the hypothesis: 'This effect is even stronger for employee commitment than manager commitment.') rejected. Results of model 8 support our earlier findings on the moderating effect of the type of residence.

(Insert table 7 around here)

\section{Discussion}

\subsection{Theoretical implications, limitations of the study and future research suggestions}

As a result of the tests in the linear regression models, we could see that for employees, internal value exchange and internal vertical communication are important. For employees, internal horizontal communications and training did not lead to job 
commitment. For managers, internal vertical communication turned out to be more important than internal horizontal communication, contrary to our hypothesis 2.4. Internal value exchange and training did not lead to job commitment for managers. Although our analysis in table 7 suggested that these differences are not that large between managers and employees, these findings are interesting and worthy interpreting further. This is because although the magnitude of the difference is incomparable, we indeed could show that there are some variations in the antecedents of employee and manager commitment. The most obvious variation was discovered in the internal value exchange. Our study revealed that internal value exchange is important for employees but not for managers. Based on this finding, we suggest that future scholars should focus on the value exchange dimension of internal marketing, and other concepts that deal with 'values' (e.g. for instance, dimensions on organizational culture) in order to find out clearer differences in the antecedents to employee and manager commitment.

This finding suggest that besides customer (or resident) satisfaction (Kleinsorge \& Karney, 1992), employee job satisfaction (Bowers \& Martin, 2007; Lings \& Greenley, 2005; Mudie, 2003) and the relationship between employee and customer (or resident) satisfaction (Chang \& Chang, 2009; Liu, 2007; Peltier et al., 2008; Tsai \& Tang, 2008), commitment dimension in a service organization is an important topic to study. Employee commitment is by far the more investigated in the literature, although recent studies have introduced manager commitment (Elmadağ et al., 2008; Wang, 2014). Our study contributes to this literature by unfolding the antecedents of both employee and manager commitment and contrasting the inter-relationships between them.

Paying attention to the rejected hypotheses can reveal interesting insights. Our study discovered that while vertical communication is important for both groups, horizontal communication is not important for either groups, although such magnitude is not 
comparable. This is disappointing in the sense that the communication dimension turned out to have the same effect in the two groups. However, these results are very surprising especially for the case of managers, as against the assumption that for managers, horizontal communication is more important, vertical communication turned out to be more critical. This counter-intuitive result indicates that in terms of communication, general effort needs to be placed in the vertical dimension between managers and employees for both groups to be committed. Future research could tap into different dimensions of vertical communication (e.g. different types, routes, lengths and strength of vertical communication) to investigate whether any differences in the antecedents can be discovered between the two groups.

Furthermore, against the view of the extant literature (e.g. Ashii et al., 2008), training turned out to not be important for both employees and managers. This does not mean that our study rejects the importance of training in elderly care homes. Rather, the result might signify that training does not have a direct relationship with commitment. There might be an important mediator missing in the relationship, or training might be more directly related with other types of dependent variables such as job satisfaction (Bansal et al., 2001; Peltier et al., 2008).

Other relationships that were surprisingly not supported in the study are the moderating roles of the pubic residence. However, our results are in line with the earlier finding of Sinervo et al. (2010) that there are indeed differences between the private and the public sectors, but no clear order of superiority can be established in the Finnish elderly care sector.

Finally, our results support previous findings maintaining that organizations must implement internal marketing programs to achieve an increase in quality provision focusing on employees (Ahmed et al., 2003; Peltier et al., 2008; Peltier et al., 2012). 
Our findings build on this by suggesting that different emphases on internal value exchange is necessary to increase the commitments of employees and managers. We believe these findings are applicable, particularly in service industries where the role of employees is highlighted (e.g. industries where employees have close contact with customers).

Some research limitations are recognized in our study. First, the elements of internal marketing were limited to internal value exchange, internal vertical communication, internal horizontal communication and training. Although these four elements encompass the overlapping concepts, such as education, information generation, motivating and developing, they miss such aspects as attracting, hiring and retaining employees (Anaza et al., 2012; Ahmed et al., 2003). Thus, the problem of incongruity in its operationalization (Anaza et al., 2012; Palter et al., 2013; Wieseke et al., 2009) is not resolved. We adopted IM practices as tools to identify the antecedents of employee and manager commitment, and the purpose of the study was not to test a model of IM. Therefore, although the conceptualization of the IM practices does not relate directly to our theoretical contribution, we suggest future research to take into account this continuing problem in the internal marketing literature. In addition, we would like to acknowledge that indeed, there are other drivers of commitments in addition to IM practices. As mentioned earlier, future researchers could consider other types of antecedents to commitment, such as dimensions of organizational culture.

Another limitation is that although employee and manager commitment and the stemming differences were compared, further links to, for instance, customer (or resident) satisfaction were not explored. We recommend that additional empirical studies explore further links, especially with regard to the variable of training, building on our findings. 
Furthermore, we recognize the limitation that data was collected from only a single country: Finland. The generalizability of the findings might thus be limited to countries that have similar welfare systems to Finland. Especially, results on the moderating role of the type of residence might exhibit large differences in different countries with different welfare systems. However, we believe these findings could serve as a benchmark to less developed countries in terms of welfare, thus having high practical implications for practitioners globally. Future studies could collect two datasets from two distinct countries, and conduct cross-country studies on the same topic to see whether there are any differences.

\subsection{Practical implications}

Today's World is facing large changes in social structures, and organizations, particularly service firms, need to face such changes by improving their strategies and practices. One of the most crucial problems that developed countries are facing today is the increase in the ageing population. Finland is a country with one of the world's fastest ageing populations, where the generation of baby boomers is retiring, and the lengthened life expectancy is predicted to increase the size of the elderly population in the coming years. The diminished supply of labour is expected to inadvertently lead to a labour shortage. Additionally, the growth in the number of elderly people not only means rising pension expenditures, but also, an increased need for healthcare and other services (Statistics, Finland). According to the Ministry of Social Affairs and Health, the elderly care service in Finland has room for improvement (Ministry of Social Affairs and Health newsletter). The call for improving service quality in the elderly care homes in Finland is not just a domestic matter, it applies to other developed countries as well. For example, over the last two decades, the care home sector grew by $846 \%$ in the 
US alone (Kleisorge \& Karney, 1992), and in the coming decade, an increase of $80 \%$ is predicted (Shimshank, Lenard \& Klimberg, 2009).

Our findings might help practitioners to improve service quality in elderly care homes by unfolding the relationship between the antecedents of employee and manager commitment. Interpreting our overall findings, we note that there are indeed differences in the antecedents of employee's and managers' organizational commitments in terms of internal value exchange. In order to generate and maintain both employees' and managers' commitments, this difference need to be taken into account. Also we discovered that managers and employees increase their commitments through vertical communication and not through horizontal communication. Thus, we suggest that for both groups, it is particularly important to secure the vertical communication channel, and a rather flat organizational structure with the culture of open communication could be facilitated.

To generate and sustain employee commitment, a work environment where they feel free to access and communicate with their managers is important. Moreover, this communication cannot remain superficial, as value exchange should be conducted. This means, for instance, that managers should make efforts to understand employees' needs through face to face communications. Such internal marketing strategies might lead to an increased quality of service in elderly care homes. Indeed, as the Ministry of Social Affairs and Health in Finland implies, not only the law but the attitudes of people must change to be more caring towards elderly individuals. Facilitating open and honest communication and exchanging values in care homes is a crucial step toward improving the service quality and retention rate of both managers and employees in the health care sector. 


\section{References}

Ahmed, P.K. and Rafiq, M. (2003), "Internal marketing issues and challenges", European Journal of Marketing, Vol. 37 No. 9, pp. 1177-1186.

Ahmed, P.K., Rafiq, M. and Saad, N.M. (2003), "Internal marketing and the mediating role of organisational competencies", European Journal of Marketing, Vol. 37 No. 9, pp. 1221-1241.

Allen, N. J. and Meyer, J. P. (1990). "The measurement and antecedents of affective, continuance and normative commitment to the organization". Journal of Occupational Psychology, Vol. 63 No. 1, pp. 1-18.

Anaza, N.A. and Rutherford, B.N. (2012), "Developing our understanding of patronizing frontline employees", Managing Service Quality, Vol. 22 No. 4, pp. 340-358.

Andreassen, T.W. and Olsen, L.L. (2008), "The impact of customers' perception of varying degrees of customer service on commitment and perceived relative attractiveness”, Managing Service Quality, Vol. 18 No. 4, pp. 309-328.

Ashill, N.J., Rod, M. and Carruthers, J. (2008), “The effect of management commitment to service quality on frontline employees' job attitudes, turnover intentions and service recovery performance in a new public management context", Journal of Strategic Marketing, Vol. 16 No. 5, pp. 437-462.

Ballantyne, D. (2003), “A relationship-mediated theory of internal marketing", European Journal of Marketing, Vol. 37 No. 9, pp. 1242-1260.

Bansal, H., Mendelson, S., Morris B. and Sharma, B. (2001), "The impact of internal marketing activities on external marketing outcomes", Journal of Quality Management, Vol. 6 No. 1, pp. 61-76. 
Bansal, H.S., Irving, P.G. and Taylor, S.F. (2004), "A three-component model of customer to service providers", Journal of the Academy of Marketing Science, Vol. 32 No. 3, pp. 234-250.

Bellou, V. and Thanopoulos J. (2006), "Enhancing service quality in a hospital setting", Review of Business, Vol. 27 No. 1, pp. 26-32.

Berry, L. (1995), On Great Service, Free Press, Lexington, MA.

Berry, L., Hensel, J.S. and Burke, M.C. (1976), "Improving retailer capability for effective consumerism response”, Journal of Retailing, Vol. 52 No. 3, pp. 3-14.

Berry, L. and Parasuranam, A. (1991), Competing Through Quality, Free Press, New York.

Bowers, M. and Martin, C. (2007), “Trading places redux: employees as customers, customers as employees", Journal of Services Marketing, Vol. 21 No. 2, pp. 8898.

Böckerman, P., Johansson, E. and Saarni, S. (2011), "Institutionalisation and quality of life for elderly people in Finland”, ENEPRI Research Report, No. 92.

Cahill, D.J. (1995), “The managerial implications of the learning organization: a new tool for internal marketing", Journal of Services Marketing, Vol. 9 No. 4, pp. 4351.

Chang, C.S. and Chang, H.C. (2009), "Perceptions of internal marketing and organizational commitment by nurses", Journal of Advanced Nursing, Vol. 65 No. 1, pp. 92-100.

Cheung, M.F. and To, W.M. (2010), "Management commitment to service quality and organizational outcomes”, Managing Service Quality, Vol. 20 No. 3, pp. 259272. 
Churchill, G.A. (1979), “A paradigm for developing better measures of marketing constructs", Journal of Marketing Research, Vol. 16 No. 1, pp. 64-73.

Cooper, J. and Cronin, J.J. (2000), "Internal marketing: a competitive strategy for the long-term care industry”, Journal of Business Research, Vol. 48 No. 3, pp. 177181.

Elmadağ, A.B., Ellinger, A.E. and Franke, G.R. (2008), “Antecedents and consequences of frontline service employee commitment to service quality", The Journal of Marketing Theory and Practice, Vol. 16 No. 2, pp. 95-110.

Ferdous, A.S. (2008), "Integrated internal marketing communication (IIMC)", Marketing Review, Vol. 8 No. 3.

Foreman, S.K. and Money, A.H. (1995), "Internal marketing: concepts, measurement and application”, Journal of Marketing Management, Vol. 11 No. 8, pp. 755-68.

Ghosh Hazra, S. and Srivastava, K.B. (2009), "Impact of service quality on customer loyalty, commitment and trust in the Indian banking sector", The IUP Journal of Marketing Management, Vol. 8 No. 3, pp. 74-95.

Gill, L., White, L. and Cameron, I.D. (2011), "Service co-creation in community-based aged healthcare", Managing Service Quality, Vol. 21 No. 2, pp. 152-177.

Gounaris, S. (2008), “The notion of internal market orientation and employee job satisfaction: some preliminary evidence", Journal of Services Marketing, Vol. 22 No. 1, pp. 68-90.

Grönroos, C. (1990), Service Management and Marketing: Managing the Moment of Truth in Service, Lexington Books, Massachusetts.

Gummesson, E. (1991), "Marketing orientation revisited: the crucial role of the parttime marketer", European Journal of Marketing, Vol. 25 No. 2, pp. 60-75. 
Gustafsson, A., Johnson, M.D. and Roos, I. (2005), "The effects of customer satisfaction, relationship commitment dimensions, and triggers on customer retention", Journal of Marketing, Vol. 69 No. 4, pp. 210-218.

Hair, J.F., Black, W.C., Babin, B.J. and Anderson, R.E. (2010), Multivariate Data Analysis (7th edition), Prentice Hall, USA.

Hur, W.M., Park, J. and Kim, M. (2010), "The role of commitment on the customer benefits-loyalty relationship in mobile service industry", The Service Industries Journal, Vol. 30 No. 14, pp. 2293-2309.

Institute for Digital Research and Education, "SPSS FAQ How can I compare regression coefficients between two groups?", available at: http://statistics.ats.ucla.edu/stat/spss/faq/compreg2.htm (accessed 6.2.2014).

Jones, T., Taylor, S.F. and Bansal, H.S. (2008), "Commitment to a friend, a service provider, or a service company—are they distinctions worth making?", Journal of the Academy of Marketing Science, Vol. 36 No. 4, pp. 473-487.

Kleinsorge, I.K. and Karney, D.F. (1992), "Management of nursing homes using Data Envelopment Analysis”, Socio-Economic Planning Sciences, Vol. 26 No. I, pp. $57-71$.

Laine, M., van der Heijden, B.I., Wickström, G., Hasselhorn, H.M. and Tackenberg, P. (2009), "Job insecurity and intent to leave the nursing profession in Europe", The International Journal of Human Resource Management, Vol. 20 No. 2, pp. 420-438.

Lings, I.N. and Greenley, G.E. (2005), “Measuring internal market orientation”, Journal of Service Research, Vol. 7 No. 3, pp. 290-305. 
Liu, L.F. (2007), "Job satisfaction of Certified Nursing Assistants and its influence on the general satisfaction of nursing homes residents: an exploratory study in southern Taiwan", Geriatric Nursing, Vol. 28 No. 1, pp. 54-62.

Meyer, J.P. and Allen, N.J. (1991), “A three component conceptualization of organizational commitment”, Human Resource Management Review, Vol. 1 No. 1, pp. 61-98.

Ministry of Social Affairs and Health (Sosiaali-ja terveysministeriö) newsletter, available at: http://www.stm.fi/en/publications/publication//_julkaisu/1550874\#en (accessed 1.1.2014).

Mowday, R.T., Steers, R.M. and Porter, L.M. (1979), "The measurement of organizational commitment”, Journal of Vocational Behaviour, Vol. 14 No. 2, pp. 224-247.

Mudie, P. (2003), “Internal customer: by design of by default?”, European Journal of Marketing, Vol. 37 No. 9, pp. 1261-1276.

Mukherjee, A. and Malhotra, N. (2006), "Does role clarity explain employee-perceived service quality? A study of antecedents and consequences in call centres", International Journal of Service Industry Management, Vol. 17 No. 5, pp. 444-473.

Osterloh, M. and Frey, B.S. (2000), "Motivation, knowledge transfer, and organizational forms", Organization Science, Vol. 11 No. 5, pp. 538-550.

Peltier, J.W. and Scovotti, C. (2005), "Relationship marketing and disadvantaged health care segments: using internal marketing to improve the vocational rehabilitation process", Health Marketing Quarterly, Vol. 22 No. 2, pp. 69-90. 
Peltier, J.W., Nill, A. and Schibrowsky, J.A. (2003), "Internal marketing, nurse loyalty and relationship marketing: an exploratory study of German nurses", Health Marketing Quarterly, Vol. 20 No. 4, pp. 63-82.

Peltier, J.W., Pointer L. and Schibrowsky, J.A. (2008), "Internal marketing and the antecedents of nurse satisfaction and loyalty”, Health Marketing Quarterly, Vol. 23 No. 4, pp. 75-108.

Peltier, J.W., Schibrowsky, J. and Nill, A. (2012), "A hierarchical model of the internal relationship marketing approach to nurse satisfaction and loyalty", European Journal of Marketing, Vol. 47 No. 5, pp. 899-916.

Prabhu, V.B. and Robson, A. (2000), “Achieving service excellence-measuring the impact of leadership and senior management commitment", Managing Service Quality, Vol. 10 No. 5, pp. 307-317.

Ramseook-Munhurrun, P., Naidoo, P. and Lukea-Bhiwajee, S.D. (2009), “Employee perceptions of service quality in a call centre", Managing Service Quality, Vol. 19 No. 5, pp. 541-557.

Randall, W.S., Gravier, M.J. and Prybutok, V.R. (2011), "Connection, trust, and commitment: dimensions of co-creation?", Journal of Strategic Marketing, Vol. 19 No. 1, pp. 3-24.

Richard, J.E. and Zhang, A. (2012), “Corporate image, loyalty, and commitment in the consumer travel industry", Journal of Marketing Management, Vol. 28 No. 5-6, pp. 568-593.

Ruizalba, J.L., Bermúdez-González, G., Rodríguez-Molina, M.A. and Blanca, M.J. (2014), "Internal market orientation: an empirical research in hotel sector", International Journal of Hospitality Management, Vol. 38, pp. 11-19. 
Saffold, G.S., III (1988), “Traits, strength, and organizational performance: moving beyond "strong" culture", Academy of Management Review, Vol. 13, No. 4, pp. $546-558$.

Sasser, W.E. and Arbeit, S.P. (1976), "Selling jobs in the service sector", Business Horizons, Vol. 19 No. 3, pp. 61-65.

Shimshak, D.G, Lenard, M.L. and Klimberg, R.K. (2009), "Incorporating quality into data envelopment analysis of nursing home performance: a case study", Omega, Vol. 37 No. 3, pp. 672-685.

Sinervo, T. et al. (2010), Yksityinen vai kunnallinen palveluasuminen? Kustannukset, asiakasrakenne, hoidon laatu ja henkilöstön hyvinvointi (Private or social service housing? Costs, customer structure, the quality of management and staff welfare), Report 34, Helsinki, National Institute for Health and Welfare.

Stan, S., Landry, T.D. and Evans, K.R. (2004), "Boundary spanners' satisfaction with organizational support services: an internal communications perspective", Journal of Relationship Marketing, Vol. 3 No. 2-3, pp. 43-63.

Statistics Finland, available at: http://www.stat.fi/tup/suomi90/joulukuu_en.html (accessed 1.1.2014).

Stershic, S. (1994), "New imperative for service management", Marketing News, pp. 22-23.

Thornton, P.M. (1994), "Surviving in the 1990s through integrated marketing”, Nursing Homes, pp. 38-40.

Tsai, Y. and Tang, T.W. (2008), "How to improve service quality: internal marketing as a determining factor", Total Quality Management, Vol. 19 No. 11, pp. 11171126. 
Tynkkynen, L. (2013), “Towards Partnership? Studies on public-private collaboration in health and elderly case services in Finland", Academic dissertation, Juvenes Print, University of Tampere, Finland.

Varey, R.J. (1995), “Internal marketing: a review and some interdisciplinary research challenges", International Journal of Service Industry Management, Vol. 6 No. 1, pp. 40-63.

Wang, E.S.T. (2014), "Moderators of the relationship between social bonding and organizational commitment”, Managing Service Quality, Vol. 24 No. 3, pp. 300314.

Wieseke, J., Ahearne, M., Lam, S.K. and Dick, R.V. (2009), "The role of leaders in internal marketing", Journal of Marketing, Vol. 73 No. 2, pp. 123-145.

Willem, A., Buelens, M. and De Jonghe, I. (2007), "Impact of organizational structure on nurses' job satisfaction: a questionnaire survey", International Journal of Nursing Studies, Vol. 44, pp. 1011-1020.

World Health Organization (2009), "Nurses and midwives: a force for health", Survey on the Situation of Nursing and Midwifery in the Member States of the European Region of the World Health Organization, available at: http://www.euro.who.int/data/assets/pdf_file/0019/114157/E93980.pdf (accessed 11.7.2010).

Zeithaml, V.A., Parasuraman, A. and Berry, L.L. (1990), Delivery Quality Service: Balancing Customer Perceptions and Expectations, The Free Press, New York, NY. 


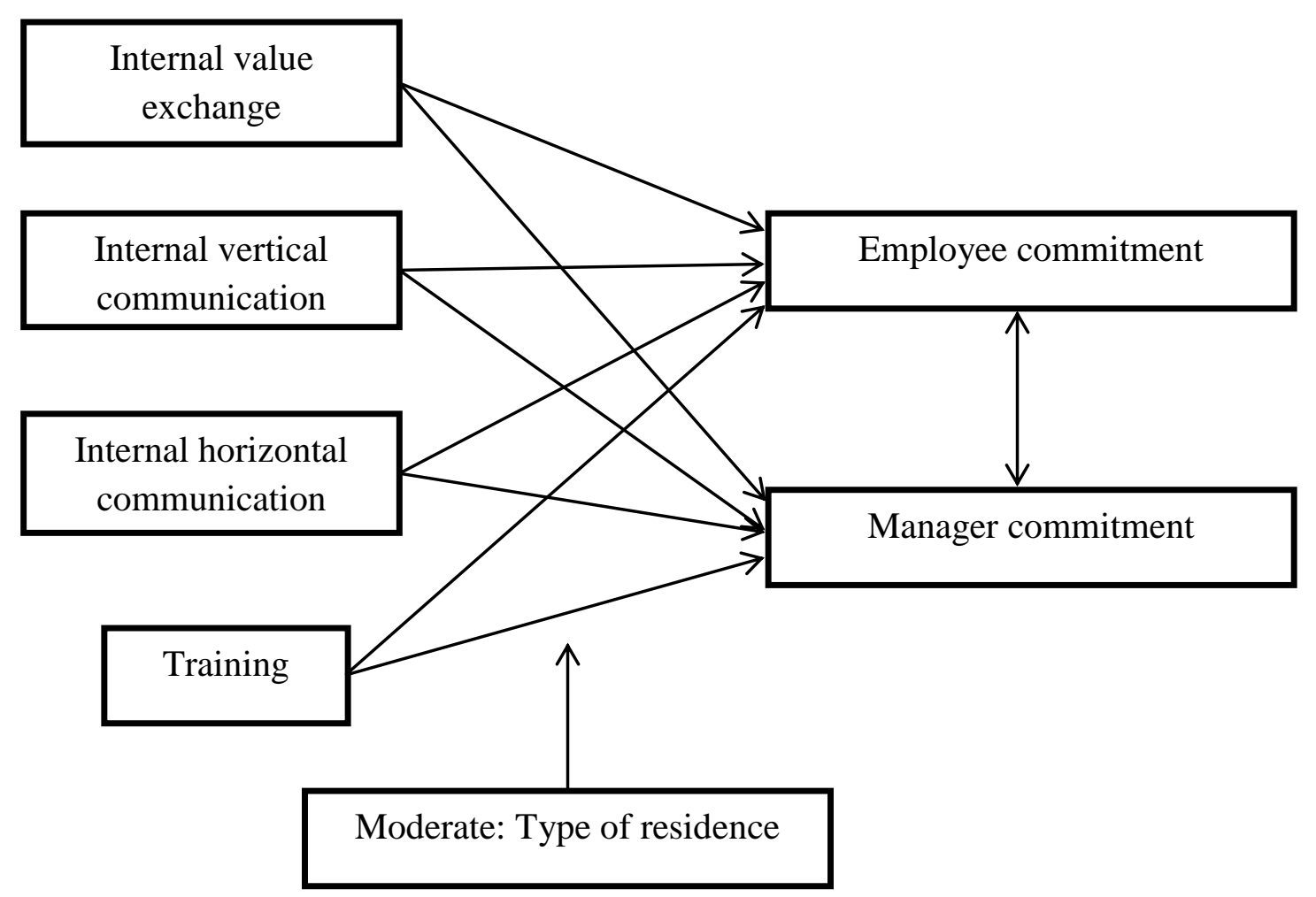

Figure 1: Proposed theoretical model 
Table 1: Measures used in the study

\begin{tabular}{|c|c|}
\hline $\begin{array}{l}\text { Internal value } \\
\text { exchange }\end{array}$ & $\begin{array}{l}\text { 1. One of this company's priorities is to understand the needs of } \\
\text { its employees before any decisions are made. } \\
\text { 2. We make sure we meet our employees face to face to better } \\
\text { understand their needs. } \\
\text { 3. In this company, we regularly conduct studies to identify our } \\
\text { employees' needs and expectations. } \\
\text { 4. An important aspect of our work is to check whether our } \\
\text { employees are satisfied with their jobs and to identify any } \\
\text { problems they might have. }\end{array}$ \\
\hline $\begin{array}{l}\text { Internal vertical } \\
\text { communication }\end{array}$ & $\begin{array}{l}\text { 1. Our managers are genuinely interested in listening to what } \\
\text { employees have to say about their work, any problems they } \\
\text { might have and the suggestions they put forward. } \\
\text { 2. If employees have a personal problem that has a negative } \\
\text { effect on their performance, we encourage them to talk to their } \\
\text { manager about it. } \\
\text { 3. The managers in this company are always available to meet } \\
\text { personally with an employee if such a meeting is requested. } \\
\text { 4. Managers are expected to spend time with employees, } \\
\text { explaining to them the company's objectives and how these } \\
\text { objectives affect what the company expects from each individual } \\
\text { employee. }\end{array}$ \\
\hline $\begin{array}{l}\text { Internal } \\
\text { horizontal } \\
\text { communication }\end{array}$ & $\begin{array}{l}\text { 1. The managers of different departments meet periodically to } \\
\text { discuss problems with employees and consider possible } \\
\text { solutions. } \\
\text { 2. If an employee in a department has a problem, the managers } \\
\text { from other departments are usually quickly informed. } \\
\text { 3. This company encourages managers to meet up and deal with } \\
\text { problems with employees. } \\
\text { 4. The idea to solve a specific problem with an employee is } \\
\text { sometimes a suggestion from a manager from another } \\
\text { department. }\end{array}$ \\
\hline Training & $\begin{array}{l}\text { 1. Prior to implementing a new service, or modifying an existing } \\
\text { one, employees are given extensive training in relation to the } \\
\text { change and how it will affect their way of working. } \\
\text { 2. This company systematically and continuously organizes } \\
\text { training seminars so that employees can develop their skills. } \\
\text { 3. If an employee is moved to a new task or department, his/her } \\
\text { new manager will personally provide training in relation to the } \\
\text { new role. }\end{array}$ \\
\hline Commitment & $\begin{array}{l}\text { 1. This company deserves that I do my best at work. } \\
\text { 2. I feel an emotional tie to the company. } \\
\text { 3. I would feel a bit guilty if I had to leave the company right } \\
\text { now. }\end{array}$ \\
\hline
\end{tabular}

Notes: Commitment: when the respondents are employees, the construct refers to employees' organizational commitment, and when the respondents are managers, the construct refers to managers' organizational commitment. 
Table 2: Factor analyses

\begin{tabular}{|l|r|r|}
\hline Factors & KMO & rronbach's Alpha \\
\hline IVE & 0.788 & 0.825 \\
IVC & 0.823 & 0.873 \\
IHC & 0.747 & 0.757 \\
TR & 0.700 & 0.772 \\
OC & 0.702 & 0.807 \\
\hline
\end{tabular}

Notes: IVE: Internal Value Exchange; IVC: Internal Vertical Communication; IHC: Internal Horizontal Communication; TR: Training; CO: Organizational Commitment. 
Table 3: Correlation matrix

\begin{tabular}{|c|c|c|c|c|c|c|c|}
\hline \multicolumn{2}{|l|}{ Status } & $\mathrm{OC}$ & IVE & ICV & $\mathrm{ICH}$ & TR & TYPE \\
\hline \multirow[t]{6}{*}{ Employee } & $\mathrm{OC}$ & 1 & & & & & \\
\hline & IVE & $.498^{* * *}$ & 1 & & & & \\
\hline & ICV & $.486^{* *}$ & $.754^{* *}$ & 1 & & & \\
\hline & $\mathrm{ICH}$ & $.216^{*}$ & $.324^{* *}$ & $.342^{\text {** }}$ & 1 & & \\
\hline & TR & $.310^{* *}$ & $.615^{* *}$ & $.716^{* *}$ & $.369^{* *}$ & 1 & \\
\hline & TYPE & -.017 & .075 & .053 & .089 & .033 & 1 \\
\hline \multirow[t]{6}{*}{ Manager } & OC & 1 & & & & & \\
\hline & IVE & $.410^{* * *}$ & 1 & & & & \\
\hline & ICV & $.421^{* * *}$ & $.560^{* *}$ & 1 & & & \\
\hline & $\mathrm{ICH}$ & $.382^{* *}$ & $.305^{* *}$ & .165 & 1 & & \\
\hline & TR & $.398^{* * *}$ & $.402^{* *}$ & $.478^{* *}$ & $.355^{* *}$ & 1 & \\
\hline & TYPE & $.312^{* *}$ & $.234^{*}$ & .146 & .132 & .174 & 1 \\
\hline
\end{tabular}

\section{Notes:}

**. Correlation is significant at the 0.01 level (2-tailed).

*. Correlation is significant at the 0.05 level (2-tailed). 
Table 4: Descriptive statistics and independent samples T-tests

\begin{tabular}{|c|c|c|c|c|c|c|c|c|}
\hline & & $\mathrm{N}$ & Mean & SD & Minimum & Maximum & $\mathrm{F}$ & Sig. \\
\hline \multirow[t]{3}{*}{ IVE } & Employee & 97 & 4.957 & 1.410 & 1.00 & 7.00 & 24.326 & .000 \\
\hline & Manager & 112 & 5.835 & .852 & 3.25 & 7.00 & & \\
\hline & Total & 209 & 5.219 & 1.316 & 1.00 & 7.00 & & \\
\hline \multirow[t]{3}{*}{ ICV } & Employee & 97 & 4.884 & 1.558 & 1.75 & 7.00 & 43.028 & .000 \\
\hline & Manager & 112 & 6.205 & .738 & 4.25 & 7.00 & & \\
\hline & Total & 209 & 5.548 & 1.326 & 1.75 & 7.00 & & \\
\hline \multirow[t]{3}{*}{$\mathrm{ICH}$} & Employee & 97 & 3.718 & 1.258 & 1.00 & 6.25 & .197 & .000 \\
\hline & Manager & 112 & 4.528 & 1.320 & 1.00 & 7.00 & & \\
\hline & Total & 209 & 4.125 & 1.349 & 1.00 & 7.00 & & \\
\hline \multirow[t]{3}{*}{ TR } & Employee & 97 & 4.280 & 1.394 & 1.33 & 7.00 & 15.658 & .000 \\
\hline & Manager & 112 & 5.517 & .987 & 2.33 & 7.00 & & \\
\hline & Total & 209 & 4.902 & 1.354 & 1.33 & 7.00 & & \\
\hline \multirow[t]{3}{*}{$\mathrm{OC}$} & Employee & 97 & 4.729 & 1.529 & 1.67 & 7.00 & 2.890 & .026 \\
\hline & Manager & 112 & 5.201 & 1.322 & 1.33 & 7.00 & & \\
\hline & Total & 209 & 4.966 & 1.444 & 1.33 & 7.00 & & \\
\hline
\end{tabular}


Table 5 Regression results for employees

\begin{tabular}{|c|c|c|c|c|c|}
\hline \multirow{3}{*}{ Variable } & \multicolumn{5}{|c|}{ Emplyee commitment } \\
\hline & Model 1 & & Model 2 & & \\
\hline & $\beta$ & s.e. & $\beta$ & s.e. & s.e. \\
\hline Constant & .84 & .89 & -.01 & .16 & .17 \\
\hline
\end{tabular}

Independent

$\begin{array}{lrrrrrr}\text { IVE } & .351 \text { x } & .15 & .351 \text { x } & .15 & .703 \text { * } & .27 \\ \text { ICV } & .317 \text { x } & .15 & .318 \text { * } & .15 & .07 & .33 \\ \text { ICH } & .69 & .12 & .08 & .13 & .19 & .22 \\ \text { TR } & -.15 & .14 & -.16 & .14 & -.12 & .29\end{array}$

Type of residence

TYPE

$\begin{array}{llll}.12 & .18 & .04 & .20\end{array}$

Interactions

TYPE*IVE

TYPE*ICV $\begin{array}{lll}-.53 & .32\end{array}$

TYPE*ICH

$.36 \quad .37$

TYPE*TR

$\begin{array}{ll}-.18 & .27\end{array}$

$-.056 \quad .329$

Maximum

VIF

3.044

3.045

14.783

R-square

.286

.29

.321

Adjusted R-

square

.255

.251 .25

F-test

9.225

7.421

4.567

$\mathrm{N}$

209

209

209

Notes:

$\mathrm{x} p<0.05$.

х $p<0.01$. 
Table 6: Regression results for managers

\begin{tabular}{lcccccc}
\hline Variable & \multicolumn{9}{l}{ Manager commitment } \\
\cline { 2 - 7 } & Model 1 & \multicolumn{3}{c}{ Model 2 } & \multicolumn{3}{c}{ Model 3 } \\
\hline \multirow{3}{*}{ Constant } & $\beta$ & s.e. & $\beta$ & s.e. & $\beta$ & s.e. \\
& $-.186 x$ & .082 & .01 & .11 & -.02 & .13
\end{tabular}

Independent

$\begin{array}{lrrrrrr}\text { IVE } & .208 & .14 & .15 & .14 & .06 & .21 \\ \text { ICV } & .33 \text { x } & .15 & .321 \text { x } & .15 & .38 & .21 \\ \text { ICH } & .258 \text { × } & .091 & .23 & .09 & .26 & .15 \\ \text { TR } & .175 & .121 & .19 & .12 & .27 & .17\end{array}$

Type of residence

TYPE

$\begin{array}{llll}-.311 x & .13 & -.25 & .17\end{array}$

Interactions

TYPE*IVE

TYPE*ICV

TYPE*ICH

TYPE*TR

$\begin{array}{rr}.19 & .29 \\ -.07 & .30 \\ -.08 & .19 \\ -.20 & .26\end{array}$

Maximum

VIF

1.657

1.658

3.765

R-square

.308

.251

.355

Adjusted R-

square

.283

.315

.298

F-test

11.933

11.219

6.25

$\mathrm{N}$

209

209

209

Notes:

* $\mathrm{p}<0.05$.

* $\mathrm{p}<0.01$. 
Table 7: Regression results testing $H O: B e=B m$

\begin{tabular}{|c|c|c|c|c|c|c|c|c|c|c|}
\hline \multirow[t]{3}{*}{ Variable } & \multicolumn{10}{|c|}{ Employee and manager commitment } \\
\hline & Model 4 & & Model 5 & & Model 6 & & Model 7 & & Model 8 & \\
\hline & $\beta$ & s.e. & $\beta$ & s.e. & $\beta$ & s.e. & $\beta$ & s.e. & $\beta$ & s.e. \\
\hline Constant & .001 & .051 & -.111 & .076 & $-.186 x$ & .09 & -.106 & .112 & -.076 & .115 \\
\hline
\end{tabular}

Independent

\begin{tabular}{|c|c|c|c|c|c|c|c|c|c|c|}
\hline IVE & $.263 x$ & .102 & $.287 x x$ & .102 & .208 & .155 & .184 & .156 & .17 & .156 \\
\hline ICV & $.248 x$ & .103 & $.274 \times x$ & .103 & $.33 x$ & .165 & $.326 x$ & .165 & .343 & .185 \\
\hline $\mathrm{ICH}$ & $.175 x$ & .076 & $.186 x$ & .075 & $.258 x$ & .101 & $.248 x$ & .101 & $.243 x$ & .101 \\
\hline $\mathrm{TR}$ & -.021 & .092 & .003 & .092 & .175 & .134 & .182 & .134 & .188 & .134 \\
\hline
\end{tabular}

Status

Employee

$\begin{array}{lllllllll}.233 x & .117 & .269 x & .121 & .284 x & .122 & .275 x & .122\end{array}$

EmpIVE

EmpICV

EmpICH

EmpTR

$\begin{array}{rrrrrr}.143 & .205 & .167 & .206 & .395 & .266 \\ -.013 & .214 & -.01 & .214 & .047 & .224 \\ -.189 & .152 & -.187 & .152 & -.014 & .221 \\ -.326 & .184 & -.327 & .184 & -.432 & .275\end{array}$

Type of

residence

TYPE

$\begin{array}{llll}-.129 & .108 & -.174 & .12\end{array}$

Interactions

EmpIVE*TYPE

EmpIDV*TYPE

EmpICH*TYPE

EmpTR*TYPE

Maximum VIF

R-square

Adjusted R-

F-test

19.248

N 
Notes:

* $p<0.05$.

\#ะ $p<0.01$. 